\title{
SPECIFIC AND NON-SPECIFIC PARAMETERS OF SIMPLICIA AND ETHANOLIC EXTRACT OF PRASMAN LEAVES (AYAPANA TRIPLINERVIS)
}

\author{
SASMITA RETNO SARI, BERNA ELYA*, KATRIN BASAH
}

Faculty of Pharmacy, Universitas Indonesia, Depok, West Java, Indonesia. Email: berna.elya@farmasi.ui.ac.id

Received: 02 October 2019, Revised and Accepted: 24 December 2019

ABSTRACT

Objective: Ayapana triplinervis (Vahl) R.M.King and H. Rob. leaves can be applied as a diuretic and as an antioxidant. Based on its medicinal properties, A. triplinervis can be used as traditional medicine. Therefore, its quality and safety should be guaranteed, which could be verified based on the outcomes of standardization processes. The aim of the present study was to evaluate some specific and non-specific parameters of simplicia and $70 \%$ ethanolic extracts of $A$. triplinervis leaves from three regions in Indonesia.

Methods: The samples were macerated using 70\% ethanol.

Results: With regard to the specific parameters of A. triplinervis simplicia, the total water-soluble extract was $18.69-29.30 \%$, the total ethanol-soluble extract was 7.73-11.78\%, and the total flavonoid content was 3.31-4.10, expressed as mg rutin equivalent (RE)/g simplicia. With regard to the nonspecific parameters, the total drying losses were 13.61-14.55\%, the total ash content was $11.54-11.83 \%$, and the total acid insoluble ash content was 1.90-2.66\%. In the extracts, the total flavonoid content was 14.94-22.41 expressed as mg RE/g extract, while for the non-specific parameters, the total water content was $11.07-12.66 \%$, the total ash content was $10.55-10.89 \%$, and the total acid insoluble ash content was $0.25-0.32 \%$.

Conclusion: The parameters identified could be used to determine the safety and stability of extracts and simplicial before administration to treat various ailments.

Keywords: Ayapana triplinervis, Non-specific parameter, Specific parameter.

(c) 2020 The Authors. Published by Innovare Academic Sciences Pvt Ltd. This is an open access article under the CC BY license (http://creativecommons. org/licenses/by/4. 0/) DOI: http://dx.doi.org/10.22159/ijap.2020.v12s1.FF026

\section{INTRODUCTION}

Ayapana triplinervis (Vahl) R.M.King and H. Rob. is a shrub belonging to the family Asteraceae, and it can be found in lowlands and at altitudes of up to $1600 \mathrm{~m}$ above sea level [1], A. triplinervis contains essential oils, coumarin derivative compounds, namely, ayapin and ayapanin and terpene [2]. In addition, A. triplinervis contains saponins, flavonoids, quercetin, rutin, alkaloids, polyphenols, carotene, and Vitamin C [3-5]. A. triplinervis leaf extracts can be used as diuretics, antipyretics, and antidiarrheal [2,4]. Based on the previous studies by Matos et al. (2014) and Melo et al. (2013), A. triplinervis leaf extracts exhibit various pharmacological activities, including antianorexic, sedative, antifungal, antiparasitic, analgesic, anticoagulant, antibacterial, and antioxidant activities [6,7].

Maceration is a method of extracting simplicia at room temperature using a solvent with shaking several times. In the maceration method, the underlying principle applied is concentration on balance. Kinetic maceration is maceration with continuous stirring, while remaceration is maceration by adding solvent repeatedly after the screening of the first mass [8].

Standardization refers to a set of parameters, procedures, and measurement methods whose results are elements related to the paradigm of pharmaceutical quality, which means to conform to standard requirements (chemistry, biology, and pharmacy), including the assurance (limits) of stability of a general pharmaceutical product. Standardization is also the process of guaranteeing that a final product (medicine, extract, or extract product) has a constant parameter value (steady), which has to be determined (designed in a formula) first [8].

Simplicia standardization means that simplicia that would be used as medicine as a raw material has to conform to the requirements in the
Ministry of Health Monograph (Materia Medika Indonesia). Extracts that are used as raw materials or pharmaceutical products must conform to the monograph of raw materials (simplicia) and standard parameters required for extract. The quality requirements for simplicia and extract consist of specific parameters and general (non-specific) parameters [8]. Therefore, the aim of this study was to investigate the specific and non-specific parameters of the simplicia and ethanol extract of $A$. triplinervis leaves.

\section{MATERIALS AND METHODS}

\section{Materials}

The prasman leaves used in this research were obtained from three different regions, namely, Bogor, Sragen, and Cikarang. All other chemicals and reagents were sourced commercially: Rutin from SigmaAldrich (Singapore), ethanol from Merck (Germany), n-hexane from Merck (Germany), ethyl acetate from Merck (Germany), methanol from Merck (Germany), formic acid from Merck (Germany), and acetic acid from Merck (Germany).

\section{Preparation of extract}

A. triplinervis samples were collected from Bogor, Sragen, and Cikarang, and identified based on microscopic and morphological characteristics at the Center for Plant Conservation Bogor Botanical Garden.

\section{Extraction}

Dried powdered prasman leaves (500 g) were macerated using 70\% ethanol and then evaporated $[8,9]$.

\section{Standardization}

Standardization was performed for simplicia and extracts. A parameter test for simplicia consists of two categories of parameters including specific parameters and non-specific parameters. Specific parameters 


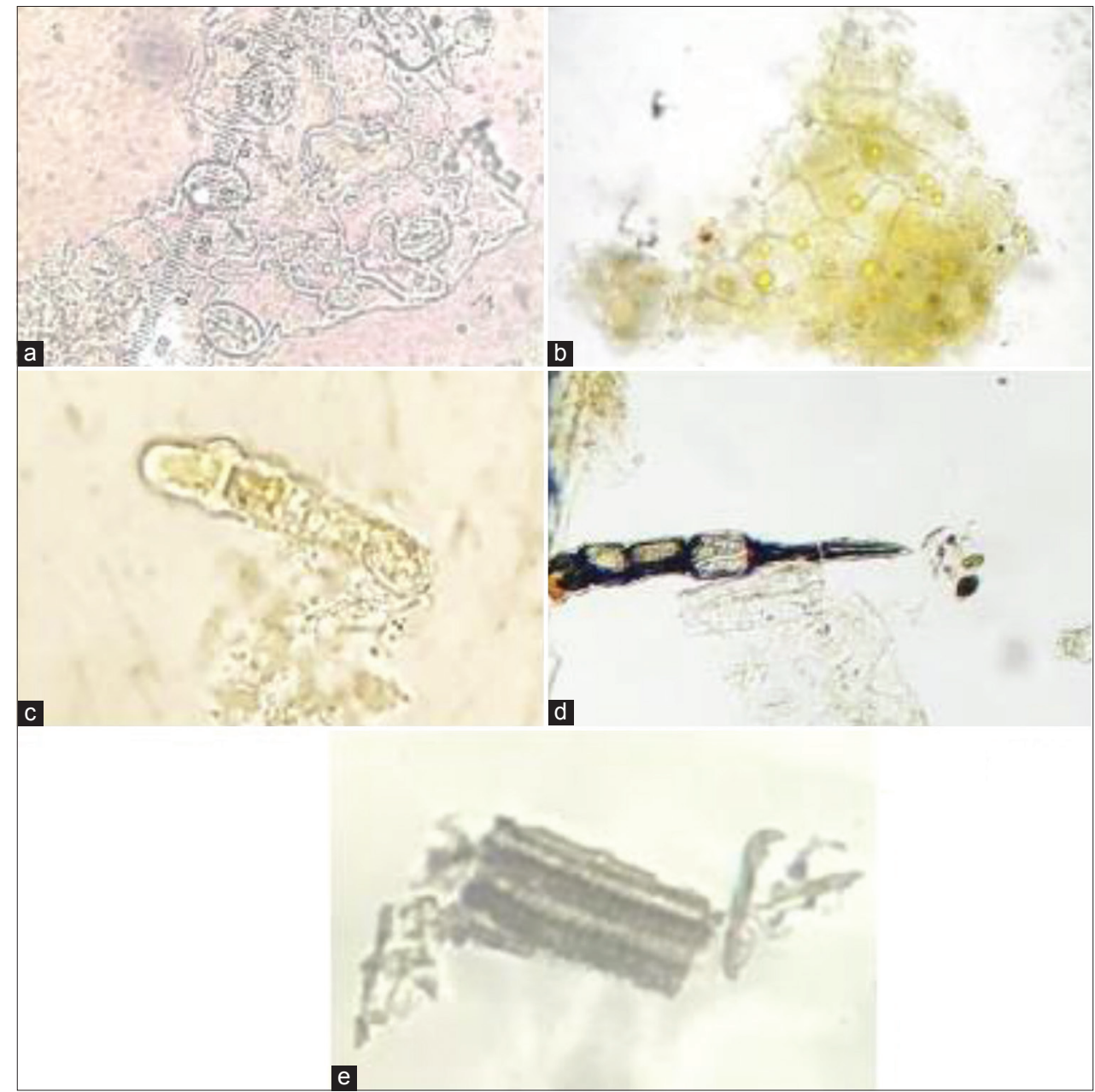

Fig. 1: Microscopic examination of Ayapana triplinervis leaf powder (×100): Lower epidermal fragments with corrugated walls, anisocytic stomata, and Compositae glandular hair (a), upper epidermal fragments with polygonal walls, oil drops (b), glandular hair (c), multicellular hair (d), vessels with spiral thickening (e)

Table 1: Parameter test results for simplicia from Ayapana triplinervis leaves

\begin{tabular}{|c|c|c|c|c|}
\hline Test & Bogor & Sragen & Cikarang & Range of values \\
\hline \multicolumn{5}{|l|}{ 1. Specific parameters } \\
\hline Water-soluble extract (\%) & 29.12 & 18.69 & 29.30 & $18.69-29.30$ \\
\hline Ethanol-soluble extract (\%) & 11.78 & 7.73 & 9.78 & $7.73-11.78$ \\
\hline Total flavonoid content & $4.09 \mathrm{mg}$ RE/g Simplicia & $3.31 \mathrm{mg}$ RE/g Simplicia & $4.10 \mathrm{mg}$ RE/g Simplicia & 3.31-4.10 mg RE/g Simplicia \\
\hline \multicolumn{5}{|l|}{ 2. Non-specific parameters $(\%)$} \\
\hline Drying losses & 13.61 & 14.48 & 14.55 & $13.61-14.55$ \\
\hline Total ash & 11.54 & 11.83 & 11.72 & $11.54-11.83$ \\
\hline
\end{tabular}

Table 2: The chromatographic profile results of rutin and Ayapana triplinervis leaf simplicia in ethyl acetate-formic acid-water-acetic acid (100:15:17:0.6) mobile phase after spraying with sitroborate spraying reagent, heating, and viewing at a wavelength of $365 \mathrm{~nm}$

\begin{tabular}{lll}
\hline Spot number & Rf value of UV $(\mathbf{3 6 6} \mathbf{~ n m})$ & Spot color \\
\hline Rutin & 0.31 & Bright yellow \\
1 & 0.31 & Light yellow \\
2 & 0.36 & Light yellow \\
3 & 0.59 & Blue \\
4 & 0.66 & Bright yellow \\
\hline
\end{tabular}

consist of macroscopic characteristics, organoleptic properties, microscopic features, water-soluble extracts, ethanol-soluble extracts, thin-layer chromatography, phytochemical composition, and chemical content, while the non-specific parameters consist of drying losses, total ash contents, and total acid insoluble ash contents [8].

A parameter test for extracts consists of two categories of parameters in the form of specific parameters and non-specific parameters. The specific parameters include organoleptic properties, phytochemical composition, and chemical content. The non-specific parameters consist of total water, total ash, and total acid insoluble ash contents [8]. 


\section{RESULTS}

Simplicia of $A$. triplinervis leaves from the three regions was similar in the form of single leaves, lanceolate-shaped leaves, leaf base and leaf tip pointed, flat-leaf edges, pinnate leaf bones, short leaf stalks, leaves 5-8 cm in length, leaves $1-2 \mathrm{~cm}$ wide, and brownish-green colored leaves. Organoleptic properties of $A$. triplinervis leaf powder from the three regions were similar in the form of dry powder, green colored powder, non-specific smell, and a fairly bitter taste. Microscopic examination of A. triplinervis leaf powder from the three regions revealed similarities in the form fragments consisting of lower epidermal fragments with corrugated walls, anisocytic stomata, Compositae glandular hair, upper epidermal fragments with polygonal walls, oil drops, glandular hair, multicellular hair, and vessels with spiral thickening (Fig. 1).

Simplicia of A. triplinervis leaves from the three regions was similarly based on their contents, including alkaloids, tannins, saponins, flavonoids, terpenoids, and glycosides. The yield extract from the three regions was $16.97-18.29 \%$. In addition, the organoleptic properties of $A$. triplinervis leaf powder from the three regions were similarly based on the viscous extract, blackish green color, distinct odor, and bitter taste. Furthermore, the A. triplinervis leaf extracts from the three regions were similar in their contents, which included alkaloids, tannins, saponins, flavonoids, terpenoids, and glycosides.

\section{DISCUSSION}

A. triplinervis leaf simplicia was prepared from samples obtained from Bogor, Sragen, and Cikarang. The sampling regions were selected based on their altitudes. Samples were wet sorted to eliminate dirt and other foreign material from the simplicia, then washed with water to remove soil and other impurities. The sample was performed to accelerate the drying process and dried in a drying cabinet to obtain simplicia

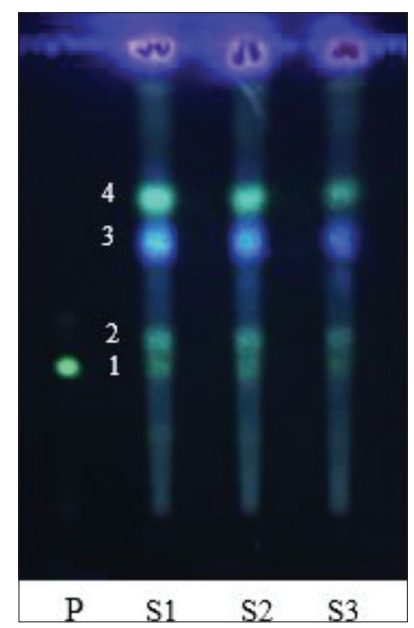

Fig. 2: The chromatogram profile of rutin and Ayapana triplinervis leaf simplicia in an ethyl acetate-formic acid-water-acetic acid (100:15:17:0.6) mobile phase after spraying with sitroborate spraying reagent, heating, and viewing at a wavelength of 365 nm: Rutin (P), A. triplinervis leaf simplicia from Bogor (S1), A. triplinervis leaf simplicia from Sragen (S2), A. triplinervis leaf simplicia from Cikarang (S3) that would not degrade easily to facilitate storage for a longer time. Simplicia that had been dried was sorted to remove foreign materials such as unwanted plant parts impurities that still existed in the dry simplicia [9].

Specific parameters are associated with original plant constituents and compounds that are responsible for pharmacological activity [8]. Conversely, the non-specific parameters are linked to environmental factors, such as contamination with compounds such as pollutants or process additives, and compounds resulting from the interaction of constituent compounds with contaminants or compounds that can change and influence drug safety and stability $[8,10]$.

The specific parameters of the simplicia consist of macroscopic tests performed to establish morphological specificity, including size and color of the simplicia. The organoleptic properties of the powder are to recognize the material as simply and objectively as possible. Microscopic features can be used to determine key characteristics of the tissues or anatomy, which could be used to identify simplicia types, as non-specific identification fragments. The water-soluble extract refers to the amount of compounds that could be absorbed by water solvents. Higher yields of the water-soluble extract compared with those of ethanol-soluble extracts indicate that simplicia contains more polar compounds so that they are more soluble in water $[8,11]$. The ethanol-soluble extract refers to the amount of compounds that can be absorbed using ethanol solvents. Phytochemical screening in A. triplinervis simplicia is performed the same as extract. A thin-layer chromatogram profile provides an initial overview of the chemical components (Fig. 2), data shown in Table 2 [8]. Flavonoids have been reported previously in A. triplinervis. Total flavonoid content determination indicated the flavonoid concentrations in the simplicia and the leaf extracts [3].

The non-specific parameters of the simplicia consist of the total drying losses, which indicate the maximum limits of the amounts of compounds lost during drying processes. Compounds that could be lost after heating at $105^{\circ} \mathrm{C}$ include water and volatile compounds such as essential oils $[8,12]$. The total ash content indicates the internal and external mineral content in simplicia, if the value of the total ash content is high, there are minerals in the simplicia $[8,13]$. The total acid insoluble ash content reveals the amount of mineral content that is not soluble in acid. A high value of the total acid insoluble ash content indicates that the product under examination has silicate components associated with soil or sand, silver, lead, or mercury $[8,14]$.

The maceration method was selected for the present study due to its relative ease and simplicity of application [15-17]. Maceration was performed using $70 \%$ ethanol as a solvent to attract all the chemical components because ethanol is a universal solvent that can attract soluble compounds in both polar and nonpolar solvents [16].

Parameter tests for the A. triplinervis leaf extracts consisted of two parameters including specific parameters and non-specific parameters. The specific parameters of the extract consisted of an organoleptic test for initial examination in a simple and objective manner. The results of phytochemical screening from simplicia is more reliable than extracts data shown in Table 1 [8]

The non-specific parameters of the extract consist of water content, which refer to the minimum range amount of water content in the

Table 3: Parameter test results for Ayapana triplinervis leaf extracts

\begin{tabular}{lllll}
\hline Test & Bogor & Sragen & Cikarang & Range of values \\
\hline $\begin{array}{l}\text { 1. Specific parameter } \\
\text { Total flavonoid content }\end{array}$ & $17.92 \%$ mg RE/g extract & $14.94 \%$ mg RE/g extract & $22.41 \%$ mg RE/g extract & 14.94-22.41\% mg RE/g extract \\
2. Non-specific parameters $(\%)$ & & & \\
$\quad$ Total water content & 11.07 & 11.28 & 12.66 & $11.07-12.66$ \\
Total ash & 10.89 & 10.70 & 10.55 & $10.55-10.89$ \\
Total acid insoluble ash & 0.32 & 0.26 & 0.25 & $0.25-0.32$ \\
\hline
\end{tabular}


extract. High yields may be observed due to the water absorbed from humidity in the environment during storage and absorption of moisture from the atmosphere during storage before inspection [8]. High water content can facilitate the growth of microbes, which would reduce the stability of an extract [17]. Total ash content illustrates internal and external mineral content in simplicia. If the value of the total ash content is high, there high mineral content in the material examined [8,13]. Total acid insoluble ash content illustrates the amounts of minerals that are insoluble in acid. A high indicates that a compound has high silicate content, potentially from soil or sand, or silver, lead, or mercury, data shown in Table 3 [8,14].

\section{CONCLUSION}

The present study presents specific and non-specific parameters from simplicia and leaf extract of $A$. triplinervis. The parameters identified could be used to determine the safety and stability of extracts and simplicial before administration to treat various ailments, considering environmental factors such as humidity could influence the quality and stability of products in storage, in addition to their cultivation conditions.

\section{ACKNOWLEDGMENTS}

The authors are thankful to Universitas Indonesia who had given financial support for this research.

\section{CONFLICTS OF INTEREST}

The authors report no conflicts of interest.

\section{REFERENCES}

1. Dalimartha S. Atlas of Indonesian Medicinal Plants. $1^{\text {st }}$ ed. Jakarta: Trubus Agriwidya; 1999

2. Department of Health, Republic of Indonesia. Materia Medika Indonesia. $6^{\text {th }}$ ed. Jakarta: Department of Health, Republic of Indonesia; 1995.

3. Roth I, Lindorf H. South American Medicinal Plants. Berlin: Springer; 2002.

4. Badan Penelitian dan Pengembangan Kesehatan: Inventaris Tanaman Obat Indonesia (I). Jakarta: Departemen Kesehatan Republik Indonesia; 1991.
5. Khare CP. Indian Medicinal Plants: An Illustrated Dictionary. New Delhi: Springer Science; 2007.

6. Matos LT, de Oliveira F, Malheiros F, de Andrade M, Monteiro M, Baetas GA. Antimicrobial bioassay-guided fractionation of a methanol extract of Ayapana triplinervis. Pharm Biol 2014;53:897-903.

7. Melo AS, Monteiro MC, da Silva JB, de Oliveira FR, Vieira JL, de Andrade MA, et al. Antinociceptive, neurobehavioral and antioxidant effects of Eupatorium triplinerve Vahl on rats. J Ethnopharmacol 2013;147:293-301

8. Department of Health, Republic of Indonesia. Common Standard Parameters of Medicinal Plant Extracts. Jakarta: Department of Health, Republic of Indonesia; 2000.

9. Prasetyo P, Inoriah E. Management of Medicinal Plant Cultivation (Simplisia Material). Bengkulu: Badan Penerbitan Fakultas Pertanian UNIB; 2013

10. Zainab Z, Gunanti F, Witasari H, Edityaningrum C, Mustofa M, Murrukmihadi M. Determination of Non Specific Standardization Parameters of Ethanol Extract of Starfruit Leaves (Averrhoa bilimbi L.). Prosiding Rakernas dan PIT IAI; 2016.

11. Muchtaridi M, Rubiyanti R, Nuruljanah H, Laila M, Asih N, Moelyono MW, et al. Determination of parameters standardization crude drug and extract arabica coffee beans (Coffea arabica L.). Int J Sci Technol Res 2017;6:61-70.

12. Yunarto N, Sulistyaningrum N. Quantitative analysis of bioactive compounds in extract and fraction of star fruit (Averrhoa carambola L.) leaves using high performance liquid chromatography. J Kefarmasian Indones 2017;7:26-33.

13. Utami YP, Umar AH, Syahruni R, Kadullah I. Standardization of simplicia and ethanol extract of leilem leaves (Clerodendrum minahassae Teisjm. and Binn.). J Pharm Med Sci 2017;2:32-9.

14. Guntarti A, Sholehah K, Irna N, Fistianingrum W. Determination of the non-specific parameters of the exthanol extract of mangosteen rind (Garcinia mangostana) on variations of regional origin. Farmasains 2015;2:202-7.

15. Azwanida NN. A review on the extraction methods use in medicinal plants, principle, strength, and limitation. J Med Aromat Plants 2015;4:196

16. Artini P, Astuti KW, Warditiani NK. Phytochemical screening of $70 \%$ ethanol extract of rhizome bangle (Zingiber purpureum Roxb.). J Farmasi Udayana 2013;2:1-4.

17. Saifudin A, Rahayu V, Teruna HY. Standardization of Natural Medicinal Ingredients. Yogyakarta: Graha Ilmu; 2011. 